\title{
ACTIVE PHILOLOGY:
}

\section{BARTHES AND NIETZSCHE}

\section{Abstract}

While the importance of Nietzsche to Barthes has long been recognized, with Barthes himself being the first to acknowledge it, this essay argues that Nietzsche's influence lies behind almost all of the major aspects of Barthes's mode of reading/writing in the 1970s, a mode that Barthes describes as 'active philology'. At the heart of this active philology is a cancellation of meaning that makes of Barthes's later critical practice a form of active nihilism in the Nietzschean sense. Exploring the various facets of this active philology in order to highlight the ways in which Barthes both follows and deviates from Nietzsche, this essay proposes an understanding of Barthes the active philologist as the incarnation of what Nietzsche terms the 'last nihilist' — and, crucially, one for whom any kind of Nietzschean overcoming of nihilism is anathema.

Tandis que l'importance de Nietzche pour Barthes est bien connue, ce dernier étant le premier à la reconnaître, cet essai entend démontrer que l'influence de Nietzsche se vérifie en particulier dans les rapports que Barthes entretenait à l'écriture et à la lecture dans les années 1970, qu'il qualifie de 'philologie active'. Au cœur de cette philologie active, il y a une annulation du sens qui fait de la dernière pratique barthésienne de la critique une forme de nihilisme active au sens nietzschéen. En explorant les multiples facettes de cette philologie active, il est possible de mesurer les convergences et les écarts de Barthes par rapport à Nietzsche. Cet essai se propose de présenter Barthes comme l'incarnation de ce que Niestzche appelait le 'dernier nihiliste' et de manière cruciale, comme quelqu'un qui voulait eviter toute tentative nietzschéenne de dépassement du nihilisme. 
In many respects, it is hard to imagine a critical voice more quintessentially French than that of Roland Barthes. From the early 1950s onwards, the focus of his published works remained largely French literature and culture. In addition to books on Michelet, Racine, Balzac, and Sollers, Barthes also devoted essays to a wide range of French writers, including La Rochefoucauld, La Bruyère, Diderot, Sade, Chateaubriand, Fourier, Stendhal, Flaubert, Baudelaire, Proust, Bataille, and Robbe-Grillet. In striking contrast, there are no published essays devoted entirely to any English-language writer, and relatively few on works by nonFrench European writers. To this profile might be added Barthes's decidedly French appreciation of Japanese culture, reflected most notably in L'Empire des signes (1970), as well as the fact that his principal methodological shifts, from Marxist-inspired ideology critique, to structuralism, to post-structuralism, were shaped in no small measure by interventions within French literary-philosophical discourse, from Saussure, to Lacan, to Deleuze, and then Derrida.

These national-linguistic limits to Barthes's critical interests are also reflected in his self-acknowledged lack of competence in any foreign language. As a critic whose attention was directed above all to the ways in which texts signify — that is, to questions of style, code, and system - it is perhaps unsurprising that, in his analysis of literature, Barthes should have restricted himself largely to works originally written in the only language in which he felt at ease. Indeed, as Barthes himself put it as late as 1979: 'je n'aime vraiment que ce qui est écrit en français'. ${ }^{1}$ This linguistic limitation makes all the more significant the two great exceptions to it, both of which point to the profound impact (albeit in translation and in partially mediated form) of two very different voices from German culture.

\footnotetext{
${ }^{1}$ Roland Barthes, 'Roland Barthes s'explique' (1979), in Euvres complètes, 3 vols, ed. Éric Marty (Paris: Éditions du Seuil, 1995), III, pp. 1068-79 (p. 1077).
} 
Towards the end of his remarkable (auto)biographical work Roland Barthes par Roland Barthes (1975), Barthes breaks his writing life down into five 'phases', the first of which is characterized only by the desire to write. For the other four, he identifies an 'intertexte', a 'genre', and the major published works that fall within that phase. ${ }^{2}$ With three exceptions, the intertexts in question are all Francophone: Gide for the first phase; Sartre for the second; Saussure for the third; and Sollers, Kristeva, Derrida, and Lacan for the fourth. The exceptions are Marx and Brecht (alongside Sartre) for the second phase, and Nietzsche as the sole intertext for the fifth. For the phase shaped by the impact of Marx and Brecht, the corresponding genre is identified as 'mythologie sociale', and the works written in this genre as Le Degré zéro de l'écriture (1953), Mythologies (1957), and the essays on the theatre. It would be fair to say, however, that Brecht's influence extends well beyond that second phase insofar as the German playwright and dramatic theorist's core idea of an 'alienation effect' (Verfremdungseffekt) clearly played a decisive role in the shaping of Barthes's own notions of critical denaturalization and demythologization. In Barthes's sustained critique of myth, doxa, and stereotypes, and his abiding commitment to exposing the seemingly natural as the culturally or, more precisely, ideologically constructed, Brecht the theorist remained an abiding touchstone for him.

As for the other German intertext - for what Barthes saw as his current and, as it would prove, final phrase - Nietzsche's name is placed in parentheses in Barthes's table, as is that of Gide, whose novel L'Immoraliste (1902) was doubtless one of the early sources for what would prove to be Barthes's highly mediated encounter with Nietzsche's thought. Although he glosses the terms 'intertexte' and 'genre', Barthes does not explain why he has chosen to place the names Gide and Nietzsche in parentheses. It seems clear, however, that some attempt at a distancing or limitation is taking place here — in Nietzsche's case, that

\footnotetext{
${ }^{2}$ Roland Barthes, Roland Barthes par Roland Barthes, in Euvres complètes, III, pp. 78-252 (pp. 205-6).
} 
limitation is in no small part the fact that Barthes's encounter with the German philosopher's work was not only in translation but also largely by way of the work of other French thinkers on Nietzsche. If there is indeed such an attempt to distance or limit the Nietzsche intertext here, it is compromised not least by the fact that Barthes's own thinking of intertext in the mid-1970s is itself profoundly Nietzschean in the emphasis that it places upon metaphor. An intertext is, Barthes insists, not necessarily a 'champ d'influences'; rather, it is a 'musique de figures, de métaphores, de pensées-mots'. ${ }^{3}$ Alongside this emphasis upon the musical and the metaphorical, Barthes assertion that 'moralité' is the genre into which works such as $L e$ Plaisir du texte (1973) and Roland Barthes par Roland Barthes fall only reinforces the decisive role played by Nietzsche's thought in Barthes's conception of this phase in his writing life. In Roland Barthes, he notes that his conception of morality is in fact the very antithesis of what is commonly understood by morality; for it is 'la pensée du corps en état de langage'. ${ }^{4}$ As he puts it in his 1973-4 seminar at the École Pratique des Hautes Études on 'Le Lexique de l'auteur', morality in this Nietzschean sense is to be understood as what Nietzsche terms 'l'expression corporelle'. ${ }^{5}$ To think morality in this way, as the body become language,

\footnotetext{
${ }^{3}$ Barthes, Roland Barthes, p. 206. In his 1973-4 seminar at the École Pratique des Hautes Études on 'Le Lexique de l'auteur', Barthes asserts that a writing of 'pensées-mots' is not to be confused with a style, and that, among the philosophers, Nietzsche alone has achieved such a writing (see Roland Barthes, Le Lexique de l'auteur. Séminaire à l'École pratique des hautes etudes 1973-1974. Suivi de fragments inédits du 'Roland Barthes par Roland Barthes', ed. Anne Herschberg Pierrot (Paris: Éditions du Seuil, 2010), pp. 62, 129).

${ }^{4}$ Barthes, Roland Barthes, p. 206.

${ }^{5}$ Barthes, Le Lexique de l'auteur, p. 59. Barthes is citing here from a note by Nietzsche included in The Will to Power: 'Je considère la moralité grecque [...] comme la plus haute qui ait été jamais; ce qui me le prouve, c'est qu'elle a porté à son comble l'expression corporelle. Mais la moralité à laquelle je pense est la moralité effective du peuple, non celle des philosophes' (Nietzsche cited in ibid., pp. 59-60).
} 
thus clearly owes much to Nietzsche's own thinking of the body and its intimate, nonCartesian, relation to thought. ${ }^{6}$

According to Philippe Sollers, who knew him well, Barthes was a 'lecteur de Nietzsche, comme peu l'auront été, toute sa vie!', adding, with regard to Barthes's essay on his own novel $H$ (1973): 'Nietzsche, très souvent. Les citations de Nietzsche sont toujours là.' ${ }^{7}$ References to, and quotations from, Nietzsche are to be found, however, predominantly in Barthes's works from the 1970s, reaching their most extensive in the Collège de France lecture courses delivered between 1976 and Barthes's untimely death in spring $1980 .{ }^{8}$ Beyond his conceptions of intertext and morality, Barthes would, in the course of the 1970s, deploy a large number of Nietzschean topoi in his work. As we shall see, these topoi plays a decisive role in the emergence of Barthes's conception — and, above all, his practice — of what (taking the term from a work on, rather than by, Nietzsche) he describes as a 'philologie active'.

The Nietzschean topoi that are taken up by Barthes in the 1970s include the idea of modernity as characterized principally by a 'crise de vérité' and by a nihilistic 'aplatissement des valeurs'; the conviction that all concepts are metaphors; that there are no facts, only interpretations $;{ }^{9}$ that knowledge is irreducibly perspectival; that subjectivity is discontinuous; and that modernity's determining struggle is between the 'artist' and the 'priest', the former standing against the 'herd' (that is, against all forms of 'doxa', and against the moral 'facts'

\footnotetext{
${ }^{6}$ In La Préparation du roman, Barthes declares that he sees things in precisely the way in which they are seen in Nietzsche's Ecce Homo; that is, in relation to the 'choix du corps'. (Roland Barthes, La Préparation du roman. Cours au Collège de France 1978-1979 et 1979-1980, ed. Nathalie Léger (Paris: Éditions du Seuil, 2015)

${ }^{7}$ Philippe Sollers, L'Amitié de Roland Barthes (Paris: Éditions du Seuil, 2015), pp. 26, 30.

${ }^{8}$ Like Sollers, Anne Herschberg asserts that Barthes had been reading Nietzsche 'depuis longtemps'. However, she adds the important qualification that, in his notes for his 1973-4 seminar on 'Le Lexique de l'auteur', Barthes cites from the Nietzsche anthology edited by Jean Grenier, Vie et vérité, published in 1971 (Anne Herschberg, 'Presentation', in Barthes, Le Lexique de l'auteur, pp. 23-39 (p. 24)).

9 In a fragment entitled 'Déjouer' in his essay on Georges Bataille's Le Gros Orteil, Barthes cites Nietzsche when clarifying that, when knowledge is 'émietté', this entails not its destruction but its displacement (Roland Barthes, 'Les Sorties du texte' (1973), in Euvres complètes, II, pp. 1614-22 (p. 1617))
} 
purveyed by the 'priest'). ${ }^{10}$ For this Nietzschean 'artist', pathos and dramatization are central to an 'aesthetic justification' of existence that would supplant any moral justification thereof. ${ }^{11}$ Perhaps the most dramatic statement in Barthes's œuvre regarding this Nietzschean commitment to pathos and dramatization comes towards the end of La Chambre claire (1980), when Barthes remarks upon his affective relation to those photographs by which he had been "'point"'. He confesses: 'j'entrais follement dans le spectacle, dans l'image, entourant de mes bras ce qui est mort, ce qui va mourir, comme le fit Nietzsche, lorsque, le 3 janvier 1889, il se jeta en pleurant au cou d'un cheval martyrisé: devenu fou pour cause de Pitié.' ${ }^{12}$ An earlier, more sustained example of Nietzsche-inspired dramatization is Barthes's decision to take on the role of the lover in Fragments d'un discours amoureux (1977). Barthes acknowledges Nietzsche's 'influence' in this regard, adding that it was Nietzsche's insistence upon 'dramatisation' as a method that enabled Barthes to free himself from any reliance upon a metalanguage that would locate the critical voice above and beyond the personal, the

\footnotetext{
${ }^{10}$ In a late text on the Italian film-maker Michelangelo Antonioni, Barthes identifies the three 'vertus' of the artist, as distinct from the priest, as 'la vigilance', 'la sagesse', and 'la fragilité' (Roland Barthes, 'Cher Antonioni ...' (1980), in CEuvres complètes, III, pp. 1208-12 (p. 1208)). Here, as so often in the 1970s, Barthes refers explicitly to Nietzsche when making the distinction between the artist and the priest, articulated most fully in the third essay in On the Genealogy of Morals (1887): 'What is the Meaning of Ascetic Ideals?' Lucy O'Meara highlights the importance of a number of these topoi in Barthes's later work (see Lucy O'Meara, Roland Barthes at the Collège de France, Contemporary French and Francophone Cultures 22 (Liverpool: Liverpool University Press, 2012), especially ch. 2).

${ }^{11}$ Friedrich Nietzsche, The Birth of Tragedy, in The Birth of Tragedy and Other Writings, ed. Raymond Geuss and Ronald Spiers, trans. Ronald Spiers, Cambridge Texts in the History of Philosophy (Cambridge: Cambridge University Press, 1999), pp. 1-116 (p. 33).

${ }^{12}$ Roland Barthes, La Chambre Claire. Note sure la photographie, in Euvres complètes, III, pp. 1105-1200 (p. 1190). A few years earlier, in 1977, when seeking to defend Deleuze's work in response to a critique by Bernard-Henri Lévy, Barthes clarifies that his own thinking of pathos is Nietzschean through and through, and that, for him, as for Nietzsche, language itself is a 'passion' or a 'pathos' in the sense of a 'pathos des distances' ('Lettre à Bernard-Henri Lévy', in CEuvres complètes, III, pp. 703-4 (p. 703)). In La Préparation du roman, Barthes provides his own Nietzsche-inspired definition of 'pathos'; that is, everything that is 'de l'ordre de l'affect' (Barthes, La Préparation, p. 125).
} 
corporeal, and the perspectival. ${ }^{13}$ Nietzschean dramatization is thus in part a strategy designed to free Barthes from the lure of the scientific. A similar effect is achieved by Barthes's commitment to the Nietzschean 'pour moi', which, as he explains at the beginning of his 1973-4 seminar on 'Le Lexique de l'auteur' has a 'valeur fondatrice' for him within the 'asystème' or the 'système ouvert' of Nietzschean evaluation. ${ }^{14}$

If Nietzsche is the great philosophical diagnostician of modernity's crisis of truth, Barthes finds the most acute literary engagement with that crisis in the work of Flaubert, above all in the posthumously published Bouvard et Pécuchet (1881). This crisis is at the deepest level a form of language scepticism, in that, as Barthes puts it in 1976: 'C'est le moment où on s'aperçoit que le langage ne présente aucune garantie.' With the loss of that linguistic guarantee, it is 'la crise de la modernité qui s'ouvre'. ${ }^{15}$ Barthes's analysis of modernity thus takes its place within a modern language-sceptical tradition arising in the second half of the nineteenth century, the most sustained philosophical expressions of which in the later nineteenth and early twentieth centuries are Nietzsche's posthumously published essay 'On Truth and Lying in the Non-Moral Sense' (written in 1873; first published in 1903) and Fritz Mauthner's three-volume Beiträge zu einer Kritik der Sprache ('Contributions to a Critique of Language'; 1901-2). ${ }^{16}$

\footnotetext{
${ }^{13}$ Roland Barthes, 'Entretien' (1977), in CEuvres complètes, III, pp. 774-9 (p. 776).

${ }^{14}$ Barthes, Le Lexique de l'auteur, p. 45.

${ }^{15}$ Roland Barthes, 'La crise de la modernité' (1976), in Euvres complètes, III, pp. 434-7 (p. 435).

${ }^{16}$ For an informative overview of this language crisis, see George Steiner, 'The Retreat from the Word', in Language and Silence (London: Faber \& Faber, 1967), pp. 30-54; and Real Presences: Is There Anything in What We Say (London: Faber \& Faber, 1989). See also my essay 'Modernism and Language Scepticism', in Ulrika Maude and Mark Nixon (eds), The Bloomsbury Companion to Modernist Literature (London and New York: Bloomsbury Academic, 2018), pp. 63-79.
} 
In his 1977-8 lecture course on Le Neutre, Barthes asserts that it was Nietzsche who 'a mieux démonté (dans les deux sens du terme) le concept'. ${ }^{17}$ Barthes's argument here for a dismantling of concepts recalls, in its nominalism, that of Hugo von Hofmannthal's Lord Chandos in The Lord Chandos Letter (1902). The concept is, Barthes maintains, to be dismantled because, in its abstraction, it negates difference, reducing singularities to generalities. As for what such a dismantling of concepts actually entails, Barthes takes a decidedly Nietzschean (and, as it happens, Mauthnerian) position, namely that concepts need to be exposed as metaphors, and that they never simply reflect or map a pre-given, extralinguistic reality. As Barthes puts it in Le Neutre, to write is to 'dire non au concept', with that negation taking the form of a replacement of the concept by a metaphor. ${ }^{18}$ In this definition of writing, Barthes echoes in the clearest terms Nietzsche's celebrated claim that truth is nothing but a 'mobile army of metaphors'. ${ }^{19}$

For Barthes, Nietzsche is decisive for an understanding of modernity above all because he recognizes the determining role played by language in the construction of human reality, and, indeed, that all so-called facts are nothing but linguistic constructions. The key statement here is Nietzsche's claim that there are no facts, only interpretations. ${ }^{20}$ Citing this claim in 1967 , Barthes goes on to insist that so-called facts are always precisely that: so-called. Facts necessarily only ever have an 'existence linguistique'. However, in a paradox from which it is not possible for us ever completely to extricate ourselves, 'tout se passe comme si cette

\footnotetext{
${ }^{17}$ Roland Barthes, Le Neutre. Notes de cours au Collège de France 1977-1978, ed. Thomas Clerc (Paris: Seuil/IMEC, 2002), p. 200.

${ }^{18}$ Ibid., p. 201.

${ }^{19}$ Friedrich Nietzsche, 'On Truth and Lying in the Non-Moral Sense', in The Birth of Tragedy and Other Writings, pp. 139-53 (p. 146).

20 "Against the positivism which halts at phenomena — "There are only facts" — I would say: no, facts are just what there aren't, there are only interpretations' (Friedrich Nietzsche, Writings from the Late Notebooks, ed. Rüdiger Bittner, trans. Kate Sturge (Cambridge: Cambridge University Press, 2003), 'Notebook 7, end of 1886 spring $1887^{\prime}$, p. 139).
} 
existence n'était que la "copie" pure et simple d'une autre existence, située dans un champ extra-structural, le "reel"" ${ }^{21}$ For Barthes, again echoing Nietzsche, what follows from this insight into the purely linguistic nature of facts is that there can be no one definitive interpretation. Rather, there is an irreducible plurality of interpretations - herein lies Nietzsche's pluralism. There are no absolute facts and no absolute truths to be unearthed and communicated. Instead, interpretations vie with one another, and, for Nietzsche, are to be judged not on the extent to which they correspond to any pre-interpretative reality, but rather on the extent to which they express a will to power in its most active (rather than reactive) form..$^{22}$

As for the distinction between active and reactive forces, Barthes engages directly with Nietzsche's overriding concern in his works of the later 1880s, namely the diagnosing of 'European nihilism' and the conception of how that nihilism might be overcome. Nietzsche's conception of modernity as the culmination of a nihilism that has its twin sources in Socratic philosophy and Pauline Christianity is central to Barthes's own conception of the modern era as characterized by a radical devaluation. As Barthes puts it in 1973, in an essay on Georges Bataille, whose own work was shaped to its core by his reading of Nietzsche: rather than simply destroying value, the bourgeoisie 'l'aplatit, la rapetisse, fonde un système du mesquin'. ${ }^{23}$ Following Nietzsche, and like many other French intellectuals in the late nineteenth and twentieth centuries, Barthes identifies the petite bourgeoisie as the source of

\footnotetext{
${ }^{21}$ Roland Barthes, 'Le Discours de l'histoire' (1967), in Euvres complètes, II, pp. 417-27 (p. 425).

${ }^{22}$ Barthes refers only rarely to the concept of will to power, and when he does so, it is generally by way of Deleuze, who, in Nietzsche et la philosophie, devotes considerable attention to freeing the concept from an interpretation of it that found its most extreme manifestation in the Nazi conception of Nietzsche's philosophy. In Le Neutre, for instance, Barthes assets that Nietzsche 'n'est pas directement un "philosophe" du conflit', citing Deleuze to support this view: "'Les notions de lutte, de guerre, de rivalité ou même de comparaison sont étrangères à Nietzsche et à sa conception de la volonté de puissance”" (Barthes, Le Neutre, p. 166).

${ }^{23}$ Barthes, 'Les Sorties du texte', p. 1614.
} 
much, if not all, that is to be submitted to critique. Like George Orwell in the interwar years, Barthes considers this class to be 'dangereuse' because it 'a toujours fini par rallier aux régimes forts et fascistes'. ${ }^{24}$

Barthes takes up Nietzsche's championing of the aristocratic and the noble as the only viable counter-force to the petite bourgeoisie, arguing in Le Neutre that one of the signal characteristics of the aristocratic is 'apathie', whereas 'ce serait (thème nietzschéen) le "grégaire", le "réactif" (les faibles, les prêtres, les hommes du ressentiment) qui serait "activiste", ${ }^{25}$ Not only is Barthes's distinction here between active and reactive forces taken from Nietzsche, along with that of the herd — or 'le grégaire' 26 — but so, too, is the distinction between the artist and the priest, and indeed Barthes's very conception of value as such. As Barthes puts it in his 1973 essay on Bataille, when he deploys the term 'valeur' it is to be understood in 'un sens nietzschéen'; that is, as 'la fatalité d'un paradigm intraitable: noble/vil'. ${ }^{27}$

For Nietzsche, the countering of nihilism conceived as an absolute devaluation is to be achieved by a commitment to active (as distinct from reactive or, indeed, 'activist') forces, incarnated in the figure of the Übermensch. Significantly, however, Barthes's references to this figure are rare. Rather than to the Übermensch, and to the achieved overcoming of nihilism, Barthes's attention is drawn instead to the culmination of nihilism. Thus, for instance, he identifies the hippy as one of the contemporary potential 'pré-figures du sur-

\footnotetext{
${ }^{24}$ Roland Barthes, 'Des mots pour faire entendre un doute' (1978), in CEuvres complètes, III, pp. 919-23 (p. 920).

${ }^{25}$ Barthes, Le Neutre, p. 231.

${ }^{26}$ In 1980, Barthes observed that 'Le phénomène historique qui a l'air de se dévoiler comme ça depuis dix ans, c'est le problème de la "grégarité" - c'est un mot nietzschéen. Les marginaux se multiplient, se rassemblent, deviennent des troupeaux [...].' (Roland Barthes, 'La Crise du désir' (1973), in Euvres complètes, III, pp. 12436 (p. 1244))

${ }^{27}$ Barthes, 'Les Sorties du texte', p. 1619.
} 
homme, celle que Nietzsche assignait au nihiliste dernier, celui qui tente de généraliser et de pousser la valeur réactive au point d'empêcher qu'elle soit récupérée par quelque positivité' ${ }^{28}$ This attraction to the figure of the 'last nihilist' lies at the heart of Barthes's Nietzscheinspired conception of the nature and purpose of criticism, and at the heart of his practice of active philology in the later 1970s.

Notwithstanding Sollers's claim that Barthes was a 'lecteur de Nietzsche, comme peu l'auront été, the Nietzsche texts to which Barthes refers in the 1970s are limited primarily to two late works, On the Genealogy of Morals (1887) and Ecce Homo (1888), ${ }^{29}$ as well as to the selection of posthumously published notes that was presented (misleadingly) by its original editors under the title The Will to Power (1901). No less importantly, as becomes particularly clear in the Collège de France lecture notes, Barthes's Nietzsche was highly mediated. It has generally been assumed that the principal mediator of Nietzsche's thought for Barthes was Gilles Deleuze, whose Nietzsche et la philosophie (1962) he acknowledges having read 'bien après' it was first published, ${ }^{30}$ and to which he refers on various occasions in his Collège de France lectures. However, while Deleuze's text served as an invaluable guide to Nietzsche's thought, there is much in Deleuze's conception of Nietzsche that does not find its way into Barthes's work to any significant extent, and in certain decisive respects Barthes departs from Deleuze's take on Nietzsche as the great thinker of nihilism's overcoming. Deleuze's

\footnotetext{
${ }^{28}$ Roland Barthes, 'Un cas de critique culturelle' (1969), in Euvres complètes, II, pp. 544-6 (p. 545).

${ }^{29}$ References to Nietzsche's 'autobiography', Ecce Homo, are particularly frequent in Barthes's last lecture course at the Collège de France, La Préparation du roman, and the work is included in the reading list for the course.

${ }^{30}$ Roland Barthes, ‘À quoi sert un intellectuel?’ (1977), in CEuvres complètes, III, pp. 746-60 (p. 757). It is difficult to date with any real precision Barthes's reading of Nietzsche et le philosophie. That said, Barthes's interest in Nietzsche, as evidenced by references to his work, certainly intensifies in the later 1960s, following the publication of Derrida's L'Écriture et la différence in 1967. Another work on Nietzsche to which Barthes refers in the 1970s, although much less frequently than he does to Deleuze's text, is Pierre Klossowski's Nietzsche et le cercle vicieux (1969).
} 
overriding aim in Nietzsche et la philosophie is to present Nietzsche as a counter-philosopher to Hegel; that is, as a non-dialectical thinker who, in contrast to Hegel, assigns to the negative a subordinate role. Deleuze's Nietzsche is, in short, the philosopher of becoming, the eternal return, and the overcoming of nihilism. Barthes's Nietzsche is something quite different: he is the thinker of truth as metaphor, of play, and of writing as an 'expression corporelle'.

In certain key respects, Barthes's Nietzsche bears a far greater affinity to Derrida's than he does to Deleuze's. The decisive text in this regard is Derrida's essay 'La Structure, le signe et le jeu dans le discours des sciences humaines', first delivered on 21 October 1966 at an international colloquium on 'Les Langues critiques et les sciences de l'homme', held at Johns Hopkins University, an event at which Barthes also spoke. ${ }^{31}$ Derrida concludes this influential essay, in which he challenges the entire structuralist project to which Barthes had been committed in the 1960s, with a contrast between Rousseau and Nietzsche, placing the emphasis squarely upon the idea of play and on what Derrida sees as Nietzsche's 'affirmation d'un monde de signes sans faute, sans vérité, sans origine, offert à une interprétation active' ${ }^{32}$ By 1970, Barthes was ready to acknowledge that he was 'tout à fait pour' the notion of play, ${ }^{33}$ and he would go on in the course of that decade to develop the idea of criticism as, above all, a way to 'déjouer' those forms of thought that seek to establish stable meaning (or meanings), truth as something other than a textual function or metaphor, and any kind of critical metalanguage. As Barthes put it in 1971, for him the challenge was to 'déjouer le refoulé',

\footnotetext{
${ }^{31}$ Derrida's essay was published the following year in the essay collection L'Écriture et la différence, Collection 'Tel Quel' (Paris: Éditions du Seuil, 1967). Barthes's contribution to the colloquium was 'Écrire, verbe intransitive?' (CEuvres complètes, II, pp. 973-80).

32 Jacques Derrida, 'La Structure, le signe et le jeu dans le discours des sciences humaines', in L'Écriture et la difference, Collection Points (Paris: Éditions du Seuil, 1979), pp. 409-28 (p. 427).

${ }^{33}$ Roland Barthes, “'L'Express” va plus loin avec ... Roland Barthes' (1970), in Euvres complètes, II, pp. 1017-30 (p. 1028).
} 
with this outplaying or baffling precisely not taking being an attempt to 'le faire exploser'. ${ }^{34}$ In this commitment to the outplaying or baffling of meaning, Barthes abandons the idea of criticism as a science — that is, a Saussure-inspired semiology with the power to establish truth and knowledge. In place of such a science, Barthes commits himself to what Derrida, evoking Nietzsche, describes as an active interpretation.

Barthes's own term for this Nietzsche-inspired active (as opposed to reactive) interpretation is 'philologie active'. It is in his 1976-7 lecture course, Comment vivre ensemble, that Barthes finally identifies his own critical practice as a form of active philology:

\begin{abstract}
D’une façon générale, je suis persuadé que le rapport du mot au référent n'est pas réductible une fois pour toutes à un schème universel. Le sujet, lecteur, auditeur, a un rapport différentiel aux mots en function de leurs référents. Ce serait là une voie de recherche de la philologie active, voulue par Nietzsche: philologie des forces, des différences, des intensités. ${ }^{35}$
\end{abstract}

This call for an active philology recurs at the end of the second session of Barthes's seminars on the 'Discours-Charlus' in Proust's À la recherche du temps perdu, delivered on 30 March 1977, where Barthes offers a rather different definition of the practice: 'la Nouvelle Philologie, ou Philologie active, que voulait Nietzsche: philologie du qui et non du quoi’. ${ }^{36}$

\footnotetext{
${ }^{34}$ Roland Barthes, 'Entretien (A conversation with Stephen Heath)' (1971), in CEuvres complètes, II, pp. 12911306 (p. 1303). Elsewhere, citing Nietzsche on the 'homme moyen', Barthes states that he seeks to make meaning 'boiteux', and precisely not to destroy it (Barthes, 'Les Sorties du texte', p. 1620).

${ }^{35}$ Roland Barthes, Comment vivre ensemble. Simulations romanesques de quelques espaces quotidiens. Notes de cours et de séminaires au Collège de France, 1976-1977, ed. Claude Coste (Paris: Seuil/IMEC, 2002), p. 149. In a fragment on philology that was not ultimately included in Roland Barthes, Barthes provides an emerging conception of himself as a philologist: 'Il aime le langage, il aime le texte [...]; en somme, c'est, à la lettre, un philologue (et même, peut-être, pire: un phraséologue)' (Barthes, Le Lexique de l'auteur, p. 322).

${ }^{36}$ Barthes, Comment vivre ensemble, p. 220. For an analysis of Barthes's reading of the 'Discours-Charlus', see Thomas Baldwin, 'Charlus/z', Nottingham French Studies 53 (2014): 90-101.
} 
This definition chimes with Barthes remarks on the 'pour moi' in his seminar on 'Le Lexique de l'auteur', ${ }^{37}$ and the book that arose from that seminar: Roland Barthes par Roland Barthes.

While Nietzsche makes various remarks on philology both in the works published during his lifetime and in the various notes that were published posthumously under the title The Will to Power, he does not refer at any point explicitly to an 'active philology'. In fact, Barthes's source for this conception of his own critical practice is not Nietzsche, but rather Deleuze on Nietzsche. It is in section 1 ('Transformation des sciences de l'homme') of the chapter on 'Critique' in Nietzsche et la philosophie that Deleuze refers to an active philology: 'Nietzsche rêve d'une autre philologie, une philologie active'. Deleuze then proceeds to clarify what is to be understood by such a philology:

La philologie active de Nietzsche n'a qu'un principe: un mot ne veut dire quelque chose que dans la mesure ou celui qui le dit veut quelque chose en le disant. Et une seule règle: traiter la parole comme une activité réelle, se mettre au point de vue de celui qui parle. [...] La linguistique active cherche à découvrir celui qui parle et qui nomme. ${ }^{38}$

It is precisely this principle of the 'who' that is taken up by Barthes in Comment vivre ensemble: 'une philologie du qui et non du quoi'. As for Barthes's other definition of active philology — that is, as a philology of forces, differences, and intensities — the terminology is clearly Deleuzian.

Notwithstanding these two attempts at a definition, Barthes's conception of active philology is, first and foremost, of a critical practice that may be understood as a form of

\footnotetext{
${ }^{37}$ See Barthes, Le Lexique de l'auteur, pp. 45-50.

${ }^{38}$ Gilles Deleuze, Nietzsche et la philosophie, Collection 'Quadrige' (Paris: Presses universitaires de France, 2014), p. 115.
} 
active nihilism closely akin to Gianni Vattimo's. ${ }^{39}$ Its purpose is to weaken foundational thinking, by which is to be understood a thinking in terms of truth, knowledge, and origin. And if it is a form of hermeneutics, then it is one the purpose of which is not to establish the meaning or meanings of a text, or even an 'ouverture absolue du sens', a kind of hermeneutic anything goes, but rather what Barthes terms 'des exemptions de sens, des suppressions, des annulations de sens', ${ }^{40}$

It is in this cancellation of meaning that the nihilism of active philology lies. That Barthes does indeed conceive of what he would come to term 'active philology' as a form of nihilism is evident from his remark in 1971 that one should 'lire le texte du passé dans une visée nihiliste'. ${ }^{41}$ While he may have derived the term 'philologie active' from Deleuze, it is clear that Barthes's conception of the practice as a form of nihilism owes more to Derrida — and his Nietzsche-inspired notion of 'interprétation active' — than it does to Deleuze, for whom the emphasis in his reading of Nietzsche falls repeatedly on the overcoming of nihilism through an embracing of becoming. As Barthes also remarks in 1971, what he shares most profoundly with Derrida is 'le sentiment de participer (de vouloir participer) à une phase historique que Nietzsche appelle le "nihilisme". ${ }^{42}$ A year later, Barthes clarifies a crucial point concerning his conception of nihilism, namely that, while for him nihilism is 'la seule philosophie possible de l'état dans lequel nous sommes', that nihilism is not to mistaken for any kjnd of 'radicalité déstructive'. It is not a form of annihilation, and it is not revolutionary in spirit. Rather, it is a practice that is tactful, and that works on the margins in a discreetly

\footnotetext{
${ }^{39}$ On Vattimo's conception of 'weak thought' (pensiero debole), see, for instance, his The End of Modernity: Nihilism and Hermeneutics in Post-modern Culture, trans. Jon R. Snyder (Cambridge: Polity Press, 1988).

${ }^{40}$ Roland Barthes, 'Pour la libération d'une pensée pluraliste' (1973), in CEuvres complètes, II, pp. 1699-1709 (p. 1703). In this interview, Barthes states that Nietzsche has 'beaucoup d'importance' for him precisely because Nietzsche is a 'formulateur précisément et libérateur [...] d'une pensée pluraliste' (p. 1703).

${ }^{41}$ Roland Barthes, 'Roland Barthes critique' (1971), in Euvres complètes, II, pp. 1278-80 (p. 1280).

${ }^{42}$ Barthes, 'Entretien', p. 1294.
} 
subversive manner. The kind of Nietzschean nihilism that Barthes has in mind is one that operates within language as a form of 'réflexion' and ‘énonciation'. Such a Nietzsche-inspired nihilism is realized as linguistic acts that may appear to be 'discrètes, étouffées, marginales, courtoises même', but that can in fact be 'plus nihilistes, en profondeur, que des formes d'action apparemment plus radicales' ${ }^{43}$ Here, Barthes takes his distance not least from the soixante-huitards, and aligns himself with the kind of deconstructive approach adopted by Derrida both to texts and to institutions. ${ }^{44}$

As a form of nihilism thus conceived, active philology is a 'critique des sens', and, more radically still, a 'critique $d u$ sens' ${ }^{45}$ It is a mode of reading-writing that aims to challenge any appeal to the truth or meaning(s) of a text. It is thus precisely not a form of 'critique idéologique' of the kind practised by Barthes earlier in his career, in works such as Mythologies and the interventions collected in Essais critiques (1964), ${ }^{46}$ since, unlike ideological criticism, active philology does not assume the possibility of any unassailably scientific or metalinguistic vantage-point. Rather, working on the principle that there is no reading of a text that can be established as corresponding to the 'facts', or, indeed, to a meaning or meanings that are authoritative or final, the task of active philology becomes, as Barthes put it in 1975 , to 'libérer le texte — tous les textes — des théologies du signifié transcendantal'. Barthes makes it abundantly clear that this conception of active philology is Nietzschean in inspiration, declaring: 'il faudrait chercher du côté de Nietzsche, là où il parle

\footnotetext{
${ }^{43}$ Roland Barthes, 'Fatalité de la culture, limites de la contre-culture' (1972), in Euvres complètes, II, pp. 14737 (p. 1476).

${ }^{44}$ That said, there are occasions when Barthes does seem to conceive of the critical work as destructive. In 1970, for instance, he states that criticism's aim is to 'détruire', but with destruction here being understood 'au sens large du terme, comme on parle, par exemple, de théologie négative' (Barthes, “"L'Express” va plus loin avec ... Roland Barthes', p. 1020).

${ }^{45}$ Barthes, 'Fatalité de la culture', p. 1477 (emphasis added).

${ }^{46}$ Roland Barthes, 'Plaisir / écriture / lecture' (1972), in Euvres complètes, II, pp. 1478-89 (p. 1480).
} 
d'“ébranler la vérité"'. In place of the truth of the text, Barthes's active philology aims at the pleasure of the text.

Barthes's far from consistent, and indeed far from strictly binary, distinction between plaisir and jouissance in Le Plaisir du texte both echoes and reworks Nietzsche's highly influential distinction in The Birth of Tragedy between the Apolline and the Dionysiac, which in turn has its roots in Burke's and then Kant's distinctions between the beautiful and the sublime. According to Nietzsche, the Apolline in art is characterized by a pleasure in the beautiful, the transparent, the orderly, and the dream-image (Traum-bild), whereas the Dionysiac is characterized by a highly paradoxical pleasure in destruction, in the rending of the principium individuationis, and in intoxication (Rausch). The Dionysiac pleasure is, in short, a 'blissful ecstasy' (wonnevolle Verzückung). ${ }^{47}$ Barthes's reworking of this distinction makes of the text of plaisir one that 'contente, emplit, donne de l'euphorie'; such a text remains within the culture out of which it is produced, and it is experienced through 'une pratique confortable de la lecture'. The text of jouissance, on the other hand, is one that 'met en état de perte'; it 'fait vaciller les assises historiques, culturelles, psychologiques, du lecteur', and, crucially, it 'met en crise' the reader's 'rapport au langage'. ${ }^{48}$ Barthes's version of the Dionysiac is, then, one in which the pleasure derives above all from a language crisis.

For Barthes's active philologist, however, it cannot simply be a question of identifying texts that fall into one of these two categories; that is, texts the language of which reinforces the reader's sense of linguistic power, and texts that plunge the reader into an experience of linguistic crisis. To do so would be to fall into a labour of classification that would scarcely be active in the Nietzschean sense. Rather, Barthes seeks by way of Nietzsche to conceive, and, above all, to practice a philology that would render the texts with which it engages texts of

\footnotetext{
${ }^{47}$ Nietzsche, The Birth of Tragedy, p. 17.

${ }^{48}$ Barthes, Le Plaisir du texte (1973), in Euvres complètes, II, pp. 1493-1532 (p. 1501).
} 
pleasure, prompting an experience of linguistic crisis, while also making of the philological text itself a text of pleasure in the strong sense; that is, a text that draws the reader into an experience of loss and discomfort, provoking a crisis in the reader's relation to language.

While Nietzsche's own remarks on philology are relatively few, in the 1886 expanded edition of The Gay Science, he explicitly identifies philology as having a destructive impact on 'every faith that rests on books' ${ }^{49}$ Barthes's conception of active philology certainly seems to echo Nietzsche in that respect. However, Barthes's conception of active philology as being guided by the Nietzschean principle that all so-called 'facts' have only a linguistic existence, and thus that there is nothing but interpretation, stands in flagrant contradiction of Nietzsche's own definitions of philology in The Anti-Christ (1888), where he asserts that philology seeks precisely the 'facts' (Thatsachen), and that, in this respect, the philologist is the very antithesis of the 'theologian'. As Nietzsche puts it: 'Philology should be understood here in a very general sense, as the art of reading well [die Kunst, gut zu lesen], — to be able to read facts without falsifying them though interpretations, without letting the desire to understand make you lose caution, patience, subtlety. ${ }^{50}$ While this commitment to the 'facts' stands at odds with Barthes's non-truth-centred conception of active philology, Nietzsche's next observation in The Anti-Christ is much closer to Barthes's conception. For Nietzsche proceeds to define philology as 'ephexis in interpretation' - that is, as an hermeneutic suspension of judgement, this definition chiming with what is perhaps Nietzsche's most celebrated definition of philology, in the Preface to Daybreak (1881), as an 'art' (Kunst) — rather than a science - of 'slow reading', a 'goldsmith's art and connoisseurship of the word which has

\footnotetext{
${ }^{49}$ Friedrich Nietzsche, The Gay Science, with a Prelude in German Rhymes and an Appendix of Songs ed. Bernard Williams, trans. Josefine Nauckhoff and Adrian de Caro, Cambridge Texts in the History of Philosophy (Cambridge: Cambridge University Press, 2001), p. 222.

${ }^{50}$ Friedrich Nietzsche, The Anti-Christ: A Curse on Christianity, in The Anti-Christ, Ecce Homo, Twilight of the Idols and Other Writings, ed. Aaron Ridley and Judith Norman, trans. Judith Norman, Cambridge Texts in the History of Philosophy (Cambridge: Cambridge University Press, 2005), pp. 1-67 (p. 51).
} 
nothing but delicate, cautious work to do and achieves nothing if it does not achieve it lento'. The value of philology lies, according to Nietzsche, in its teaching us 'to read well, that is to say, to read slowly, deeply, looking cautiously, before and aft, with reservations, with doors left open, with delicate eyes and fingers'. ${ }^{51}$ This emphasis on uncertainty, on a certain scepticism, and on delicacy anticipates Barthes's own practice of an active philology.

What, though, of that practice? How, in short, is active philology to achieve a pleasure-generating cancellation of meaning? Again, Nietzsche proves to be Barthes's guide here. For active philology is, Barthes insists, a 'culture' rather than a 'method', in Nietzsche's sense. This Nietzschean distinction between two modes of approach is made at the very beginning of Barthes's first lecture course at the Collège de France, Comment vivre $e^{e n s e m b l e}{ }^{52}$ Like Derrida, for whom deconstruction is lost as soon as it becomes a method, Barthes seeks to avoid the seemingly scientific approach: a method would be grounded in principles that enable a repeatable procedure, one that does not take sufficient account of the singularities of a text and of the moment of its reading. In contrast, for Barthes, every text is a singularity, and indeed a constellation of singularities, as is every act of reading, and it is active philology's responsibility to respond in singular ways to texts. Active philology cannot, then, be a programme; it cannot ever quite know where it is going. It entails uncertainty, deviation, and surprise. As Barthes puts it in Comment vivre ensemble, culture, as distinct from method, as he understands it, enables 'une sorte de dispatching au tracé excentrique'; it makes it possible to 'tituber entre des bribes, des bornes de savoirs, de saveurs'. 53

\footnotetext{
${ }^{51}$ Friedrich Nietzsche, Daybreak: Thoughts on the Prejudices of Morality, ed. Maudemarie Clark and Brian Leiter, trans. R. J. Hollingdale, Cambridge Texts in the History of Philosophy (Cambridge: Cambridge University Press, 1997), p. 5.

${ }^{52}$ See Barthes, Comment vivre ensemble, p. 34.

${ }^{53}$ Ibid.
} 
Underlying this argument for a culture rather than a method in active philology is a particular conception of experience as such. This becomes clear when Barthes cites a passage from Klossowski's Nietzsche et le cercle vicieux (1969) on experience as discontinuous, and, crucially, on how the 'fixité du langage' conceals this existential discontinuity. Barthes describes the passage in question as 'très important', and draws from it the lesson that breaking this linguistic fixity enables us to access our 'discontinu fondamental'. ${ }^{54}$ Breaking the fixity of language is to be achieved, according to Barthes, by a process of fragmentation. This fragmentation of discourse - that is, a fragmentation of both the text or texts being read and the critical text itself — results in what Barthes terms a 'succession d'unités discontinues', or 'traits'. ${ }^{55}$ The active philologist, then, must seek to achieve a 'pulvérisation de phrases, d'images, de pensées' ${ }^{56}$

Linguistic pulverization is evident from the very outset of Barthes's writing life. He seeks to practise a form of discontinuous writing in "Notes sur André Gide et son "Journal"" (1942) and then in the book on Michelet (1954). In his notes on Gide's Journal, Barthes not only produces a series of fragments, while citing Nietzsche, but also justifies the fragmentary in terms that anticipate his later practice of active philology. Fragmentation in the notes on Gide's Journal serves, according to Barthes, to avoid enclosing Gide within a 'système', the discontinuity and incoherence of Barthes's notes being adjudged preferable to an organized commentary that would deform the (fragmentary) work on which it comments. ${ }^{57}$

In her landmark biography of Barthes, Tiphaine Samoyault cautions against simply adopting Barthes's own division of his work (in Roland Barthes par Roland Barthes) into

\footnotetext{
${ }^{54}$ Ibid., p. 52.

55 Ibid.

${ }^{56}$ Roland Barthes, 'Vingt mots-clés pour Roland Barthes' (1975), in Euvres complètes, III, pp. $315-34$ (p. 318 ).

${ }^{57}$ Barthes, 'Notes sur André Gide et son “Journal”' (1942), in Euvres complètes, I, pp. $23-33$ (p. 23 ).
} 
distinct phases. ${ }^{58}$ While there is much to support Barthes's conception of his own development, not least the growing importance of Nietzsche's thought for him in the 1970s, it is nonetheless the case that certain key aspects of what he came to conceive of as active philology are already present in Barthes's earlier work. The practice of fragmentation, which is absolutely central to Barthes's practice of active philology, is perhaps the most striking example of this, given that it has its roots in his earliest critical writing. However, it is nonetheless the case that a pulverization at the level of the phrase — and, indeed, at the level of the word - is not only most fully thematized, but also most fully realized, in the works written in the 1970s, including Roland Barthes par Roland Barthes and Fragments d'un discours amoureux, and, above all, in Barthes's notes for his Collège de France lectures between 1976 and 1980. Barthes is the first to acknowledge that, even at its most extreme, such a fragmentation of the text produces a 'faux discontinu', since it is impossible to avoid making at least some concessions to the fixity of language. However, by producing a fragmentary discourse that pulverizes the text on which it works, the active philologist is making what Barthes sees as the 'plus petite concession' to the idea of language as fixed, reliable, and meaning-conveying. ${ }^{59}$ The fragmentation of discourse is, then, the least bad approach to texts; it is, for Barthes, a way in which to fail better as a reader.

No less importantly than a commitment to discursive fragmentation, the active philologist must deploy not concepts, but 'concepts-métaphores'; that is, concepts that remain linguistic through and through, and the linguistic nature of which is never occluded or forgotten. Examples of such metaphor-concepts in Barthes's work would be the imagerepertoire, doxa, and anti-hysteria. The idea of the stadium and the punctum in La Chambre claire falls into the same category. Here, too, Nietzsche is exemplary for Barthes: 'Si le mot

\footnotetext{
${ }^{58}$ See Tiphaine Samoyault, Roland Barthes (Paris: Éditions du Seuil, 2015), p. 585.

${ }^{59}$ Barthes, 'Vingt mots-clés', p. 318.
} 
de Nietzsche est juste, si les concepts ont, comme il le dit, une origine métaphorique, alors c'est à cette origine que je me replace.' 60

It is on account of this reliance upon metaphor-concepts that active philology maintains its critical distance from philosophy, at least as that discourse has generally been conceived since Plato. ${ }^{61}$ While there is no evidence to suggest that Barthes was familiar with the work of Fritz Mauthner, ${ }^{62}$ this insistence upon the metaphorical origin of all concepts is very much in line with the Austrian philosopher's critique of what he terms 'word fetishism' (Wortfetischismus), or the mistaking of the linguistic for some extra-linguistic reality; that is, of word for world. The crucial difference is that, while Mauthner calls for a philosophical 'critique of language' (Kritik der Sprache) in order to liberate thought from this word fetishism, Barthes embraces what he sees as the purely linguistic basis of the conceptual, arguing for a philology in which the metaphorical nature of the discourse is highlighted, but not with a view to overcoming it. For Barthes, in other words, there is no beyond-themetaphorical to which the active philologist would seek to direct us. Rather, active philology's task is to remind the reader unceasingly that there is, in Derrida's words, no 'horstexte', nothing but metaphor. And, of course, if there is nothing but metaphor, then the very concept of metaphor itself has to be radically revised. ${ }^{63}$

Within this bottomless textuality, Barthes's active philologist must bring to light the processes of 'signifiance'; that is, the ways in which a sense of meaning is produced even

\footnotetext{
${ }^{60}$ Barthes, ‘À quoi sert un intellectuel?’, p. 758.

${ }^{61}$ The fundamental difference between philology and philosophy is highlighted by James Turner in Philology: The Forgotten Origins of the Modern Humanities (Princeton and Oxford: Princeton University Press, 2014), pp. 381-6. The former is essentially hermeneutic and historical; the latter conceives of itself (at least in the analytic tradition) as 'logical, deductive, precise in conclusions, dismissive of change over time' (ibid., p. 381).

${ }^{62}$ The absence of any French translation of Mauthner's Beiträge rendered it a work with which it would have been difficult for Barthes to have engaged, and there is no evidence that he did so.

${ }^{63}$ Derrida attempts such a revision in 'La Mythologie blanche', in Marges - de la philosophie, Collection 'Critique' (Paris: Les Éditions de Minuit, 1972), pp. 247-324.
} 
though no meanings ever quite establish themselves. For Barthes, this 'signifiance' takes the form of a movement from signifier to signifier, a process of becoming without end, or, to take up a Nietzschean idea that Barthes does not cite, an eternal return of text to text, rather than a movement from text to world. ${ }^{64}$ If there is a difference between avant-garde texts and other, seemingly more realist or more natural texts, then it lies only in the fact that avant-garde texts highlight their own 'signifiance', whereas other texts seek to conceal it. The active philologist's task is thus made easier by the avant-garde text — which is why Barthes on Sollers is, arguably, rather less interesting that Barthes on Balzac.

Just as active philology seeks to deal only in metaphor-concepts, while also abolishing the distinction between the literal and the metaphorical, so it aims to weaken the distinction between criticism and literature. This is reflected most obviously not only in Roland Barthes par Roland Barthes, but also in Barthes's last published work, La Chambre claire (1980), where the 'qui' prevails over the 'quoi'. While Barthes's plans in the final years of his life to write a novel might seem to indicate that he retained a clear distinction between criticism and literature, there is also much to suggest that his conception of active philology was one in which the weakening of that distinction played a crucial role. The nature of the material collected on the numerous index cards that was to be included in the novel on which he was working at the time of his death, as well as the plans for the work, under the title 'Vita Nova', make this weakening of the fiction/criticism distinction clear. ${ }^{65}$ Active philology might thus serve as the umbrella term for both strands of Barthes's writing.

\footnotetext{
${ }^{64}$ Barthes's lack of interest in the idea of eternal return is in striking contrast to the considerable attention devoted to the idea by both Deleuze and Klossowski.

${ }^{65}$ As Samoyault observes, in addition to the various plans that he drafted for this work (under the title 'Vita Nova'), there are also 1,064 index cards containing material that he wished to include in the work (see Samoyault, Barthes, p. 650). For the 'Vita Nova' plans, see Euvres complètes, III, pp. 1287-94 (facsimiles) and pp. 1299-1307 (transcriptions).
} 
The overriding aim of Barthes's Nietzsche-inspired active philology is, however, what he terms the 'annulation du sens', a form of active negativity. ${ }^{66}$ It is clear that, for Barthes, some signs are already emptied of meaning. In his reflections on Japanese culture, Barthes dwells repeatedly on the idea of the void, and in particular on the 'signe vide', ${ }^{67}$ such that the Japanese empire des signs becomes in effect an empire of empty signs. Barthes is especially attracted to the Japanese language precisely because he does not understand it. Notwithstanding this lack of knowledge, he argues that signs in Japanese culture are 'vides' because they do not refer to any 'signifié dernier', of the kind that in the West goes by the name of God, science, reason, or law.. ${ }^{68}$ This is not self-evidently the case for all signs, however, and thus the question becomes how meaning might be cancelled by the active philologist. In L'Empire des signes, it is already apparent that the empty sign can be the result of a process or procedure. The model for writing here is the Zen satori, which, Barthes argues, achieves a 'secousse du sens' so radical that it opens onto meaning's 'vide insubstituable'. ${ }^{69}$ The aim is an 'exemption de tout sens'. ${ }^{70}$ The literary genre par excellence

\footnotetext{
${ }^{66}$ Barthes defines 'le Neutre' in Nietzschean terms as 'négatif-actif' (Barthes, Le Neutre, pp. 115-16).

${ }^{67}$ See Roland Barthes, L'Empire des signes (1970), in Euvres complètes, II, pp. $743-831$ (p. 764). Examples given by Barthes of empty signs include not only graphic signs (for instance, the ' $M u$ '), but also Tokyo's city centre, a package the contents of which have been thrown away, and the mirror. Barthes contrasts the Western mirror, which he sees as a narcissistic object, in which the subject seeks its own reflection, with the Oriental mirror, which is not only 'vide', but the 'symbole du vide même des symboles' (ibid., pp. 767, 749, 780, 801).

${ }^{68}$ Barthes, “'L’Express” va plus loin avec ... Roland Barthes', p. 1024.

${ }^{69}$ Barthes, L'Empire des signes, p. 748. Later in the same book, Barthes clarifies that the satori may be understood as 'une suspension panique du langage, le blanc qui efface en nous le règne des Codes' (ibid., p. 798).

${ }^{70}$ Ibid., p. 748.
} 
for such a negation of meaning is, according to Barthes, the haiku, which 'ne veut rien dire', even though it remains 'intelligible' and is thus never pure nonsense. ${ }^{71}$

The challenge thus becomes how such an emptying of meaning might be achieved by the active philologist, as distinct from the writer of haikus. In his 1972 text on Bataille's Le Gros Orteil, in which references to Nietzsche abound, ${ }^{72}$ Barthes explains that his own text will consist of named fragments, and that in order to avoid any sense of these fragments being governed by a "rhétorique du "développement", they will be organized alphabetically, this alphabetical order being chosen because it is 'un ordre privé de sens' ${ }^{73}$ A similar approach is adopted for the organization of the fragments in both Roland Barthes par Roland Barthes and Fragments d'un discours amoureux. Even when the order is not alphabetical, however, a certain privation of meaning is achieved, or at least a countering of any rhetoric of development: this is the case for the Collège de France lecture courses. Organizational arbitrariness in the arrangement of fragments that in their turn fragment the text(s) on which they remark is, then, one of Barthes's principal strategies for cancelling a certain form of meaning; namely, teleological meaning.

That said, the cancellation of meaning is not to be unambiguously embraced by the active philologist. For the 'morality' of active philology lies precisely in its being not just an art rather than a science, but a failing art or an art of failure. Were the complete 'annulation du sens' to be achieved, then the active philologist would have failed in the worst way possible, since any such achieved cancellation of meaning would, according to Barthes, result

\footnotetext{
${ }^{71}$ Ibid., p. 794. It is thus unsurprising that Barthes should return to the haiku in his seminar on the preparation of the novel: for him, the haiku remains the genre in which the 'exemption du sens' is most fully achieved, without this negation of meaning ever resulting in nonsense.

${ }^{72}$ Barthes does not refer here directly to Bataille's own major work on Nietzsche, Sur Nietzsche, first published in a limited edition in 1945 and republished in volume VI of his Euvres complètes in 1973, the year after Barthes's essay on Le Gros Orteil.

${ }^{73}$ Barthes, 'Les Sorties du texte', p. 1614.
} 
in 'non-sens'; that is to say, 'le pire sens' ${ }^{74}$ Barthes champions the haiku in his final lecture course, La Préparation du roman, not only because it seems so profoundly counter-intuitive to focus on one of the shortest genres of literary writing when ostensibly focusing on the longest, but because, for Barthes, the haiku produces neither 'sens' nor 'non-sens' ${ }^{75}$ In other words, the haiku shows the way to the active philologist, namely how to prevent meaning from establishing itself, while at the same time avoiding the complete disappearance of meaning, which would, paradoxically, entail not just the restoration of meaning, but the reign of the worst possible meaning. ${ }^{76}$ The politics of active philology lies precisely in this recognition that there is always the threat of such a worst possible meaning in the negation of meaning.

Barthes's conception of active philology, and his practice thereof in the 1970s, is, then, shaped in numerous ways by his (highly mediated) engagement with Nietzsche's thought, and, above all, the works of the later 1880s. Barthes's debt to what he describes as the Nietzsche intertext is profound, shaping his conception of experience, subjectivity, the aesthetic and the role of the 'artist' (as distinguished from the 'priest') ${ }^{77}$ the necessity of fragmentation, the nature of interpretation, perspectivism and pluralism, concepts as metaphors, the nihilistic devaluation that characterizes modernity, pathos, dramatization, the relation of the body to language, and the weakening of the distinction between criticism and literature.

\footnotetext{
${ }^{74}$ SeeBarthes, 'Vingt mots-clés', p. 319.

75 Ibid.

76 According to Kristeva, Barthes 'donne sens au non-sens' (Julia Kristeva, Sens et non-sens de la révolte. Pouvoirs et limites de la psychanalyse I (Paris: Fayard, 1996), p. 445). However, it would be more accurate to say that Barthes recognizes that 'non-sens' has a meaning, and indeed the worst meaning; rather than bestowing meaning on non-meaning, he seeks a cancellation of meaning that remains a process rather than an achievement, and one that is unrealizable.

77 As O'Meara observes, the Nietzschean 'artist' (as opposed to the 'priest') is 'the ideal emblem of Barthes's new semiologist in Leçon' (O’Meara, Roland Barthes, p. 71).
} 
There are, however, important deviations from Nietzsche, as well as crucial variations in emphasis. While he does on occasion refer to the concept of will to power, Barthes's interest lies rather in a mode of interpretation that seeks to achieve not mastery, but precisely unmastery, uncertainty, and a necessary failure. ${ }^{78}$ Rather than the overcoming of modernity's particular form of nihilism, Barthes's active philology is itself nihilistic - this is indicated not least by Barthes's interest in the idea of the 'last nihilist' rather than in the figure of the Übermensch. Active philology is, in short, a form of active nihilism, directed towards a cancellation of meaning rather than a simple proliferation of meanings. If it often seems as though such a proliferation of meaning is in fact Barthes's aim, he repeatedly gestures towards something more radical and more necessary: meaning's annihilation. And yet, as we have seen, that annihilation remains in a very specific sense impossible, precisely because, as Barthes himself observes, the complete absence of meaning, or non-meaning, is itself a meaning, and indeed the worst form of meaning. The Nietzsche-inspired 'morality' of Barthes's active philology therefore lies in no small measure in its commitment to the impossible. The active philologist's experience of this impossibility — the impossibility of meaning's complete disappearance — is the experience of the 'last nihilist'. As Adorno observes in the section on nihilism in Negative Dialectics (1966), the overcoming of nihilism is itself the very worst form of nihilism. ${ }^{79}$ Hope for the future - not least the future of reading - lies rather in the experience of overcoming's failure. In this respect, few have failed better than the active philologist that Roland Barthes became in the 1970s, culminating

\footnotetext{
${ }^{78}$ Susan Sontag remarks upon the significant difference in tone between Nietzsche and Barthes, the former's being 'mostly aggressive' and that latter's 'affable' (Susan Sontag, 'Writing Itself: On Roland Barthes', in $A$ Barthes Reader, ed. Susan Sontag (London: Jonathan Cape, 1982), pp. vii-xxxviii (p. xvii)). This difference in tone reflects a profound difference in attitude to the question of overcoming nihilism.

79 'Acts of overcoming - even of nihilism, along with the Nietzschean type that was meant differently and yet supplied fascism with slogans - are always worse than what they overcome.' (Theodor W. Adorno, Negative Aesthetics, trans. E. B. Ashton (London: Routledge \& Kegan Paul, 1973), p. 380)
} 
in the lecture courses delivered at the Collège de France between 1976 and 1980, in which active philology finds one of its most refined and most fully realized forms. 